УДК 35.073.515/477.62

\author{
Седікова I.0. \\ кандидат економічних наук, доцент \\ кафедра менеджменту та логістики \\ E-mail: irina-sedikova@rambler.ru \\ Одеська національна академія харчових технологій \\ вул. Канатна, 112, м. Одеса, Україна, 65039 \\ Седіков Д.в. \\ студент 3-го курсу \\ факультет системи технічного захисту інформації \\ E-mail: sedikov94@mail.ru \\ Одеська національна академія зв'язку ім. О.С. Попова \\ вул. Ковальска, 1, м. Одеса, Україна, 65029
}

\title{
СУЧАСНИЙ СТАН РОЗВИТКУ ТЕЛЕКОМУНІКАЦІЙНОГО ПРОСТОРУ УКРАЇНИ
}

Проведено дослідження стану розвитку інформаційного та телекомунікаційного ринку України. Встановлено, що тенденції розвитку галузі характеризуються зростанням доходів від всіх форм діяльності. Доведено, що прискореним темпом розвиваються послуги з надання кабельного телебачення, а також доступу до мережі «Інтернет». Визначено, що основними сегментами на ринку телекомунікаційних послуг залишаються мобільний, фіксований та широкосмуговий (комп'ютерний) зв'язок, проведено аналіз рейтингу пошукових систем. логії.

Ключові слова: інформація, телекомунікації, інформаційний простір, інформатизація, інформаційні техно-

Постановка проблеми та її зв'язок з важливими науковими та практичними завданнями. Актуальність дослідження даної теми визначається тим фактом, що однією із загальносвітових тенденцій $є$ розвиток інформаційного суспільства. Динаміка цього процесу, його результати для громадян, суспільства та держави значною мірою залежать від обгрунтованості відповідної державної політки та управління, які повинні формуватись на основі достовірної, точної, своєчасної та повної інформації. На сьогодні розвиток інформаційного суспільства, поширення інформаційних технологій (IT) в усі сфери життєдіяльності людини та суспільства стали нормою подальшої еволюції цивілізації. Практично всіма фахівцями, економістами, політиками усвідомлено, що розвиток IT створює засади сучасної економіки та добробуту людини.

Аналіз останніх публікацій по проблемі. Вирішення вищезазначених завдань має базуватись на дослідженні наявних сучасних інформаційних технологій, їх застосуванні та впливу на розвиток країни. Питанням дослідження проблем розвитку інформаційної галузі, аналізу інформації як фактора виробництва, сутності інформаційних технологій і напрямів їх застосування в діяльності підприємств стали предметом дослідження в працях А. Богачевського, В. Василенка, Дж. Веллінгтона, В. Гранатурова, Н. Єрьоміна, С. Ілляшенка, В. Орлова, О. Редькіна, Є. Стрельчука, Г. Титаренка та ін. Дослідженням конкурентоспроможності на ринку телекомунікаційних послуг присвячені праці таких вчених, як I. Булах [1], А. Дзюбинський, Л. Захарченко, І. Кораблінова [2] та ін.

Формулювання цілей дослідження. Метою статті $\epsilon$ дослідження стану розвитку інформаційного та телекомунікаційного ринку України.

Виклад основних результатів та їх обгрунтування. Найбільш повне та суттєве тлумачення поняття інформатизації надано у Законі України «Про національну програму інформатизації». В ньому наголошується, що «інформація є сукупністю взаємопов'язаних організаційних, правових, політичних, соціально-економічних, науково-технічних, виробничих процесів, які направлені на створення умов для задоволення інформаційних потреб громадян та суспільства на основі створення, розвитку та використання інформаційних систем, мереж, ресурсів та інформаційних технологій, які побудовані на основі застосування сучасної обчислювальної та комунікаційної техніки» [3].

Міжнародний союз електрозв'язку (МСE) виділяє триступеневу модель, за якою країни або регіони рухаються у розвитку інформаційного суспільства. Її першим етапом є мережева готовність, яка відображається поширенням інфраструктури IT в суспільстві або країні, ступінь доступу приватних осіб, підприємств та організацій до цієї інфраструктури. Другий етап включає інтенсивність, зокрема, ступінь впровадження IT. Третій 
етап характеризується ефективністю використання IT в конкретному суспільстві або регіоні [4].

Україна рухається в розвитку інформаційного суспільства повільними темпами. Як зазначалося в «Щорічній доповіді про стан інформатизації та розвиток інформаційного суспільства в Україні за 2013 рік», країна при поточних темпах IT-розвитку відстає від інших країн, що й спостерігається сьогодні. За даними Держкомстату сукупний індекс капітальних інвестицій за період січеньберезень 2014 р. у відношенні до відповідного періоду 2013 року склав 103 \%, в той же час, в сфері «Інформація та телекомунікації» він дорівнює 92,4%. Більш того, якщо $з$ цієї сфери вилучити інформаційну або медійну частину, то обсяг капітальних інвестицій у IT-сферу складе 1288,4 млн. грн., а це менш ніж 2,5 \%.

Тенденції розвитку галузі характеризуються зростанням доходів від всіх форм діяльності. За період 2009-2013 рр. доходи збільшились на 13,4 \% і склали на грудень 2013 р. 52271,1 млн. грн. Також слід зазначити, що кожного року зростає доля надання послуг населенню. Якщо на 2009 р. доходи від надання послуг населенню складали 40,63 \% від загальних доходів від надання послуг, то вже на 2013 р. ця частина зросла до
64,65 \% [4]. Прискореним темпом розвитку характеризуються послуги з надання кабельного телебачення, а також доступу до мережі «Інтернет». За результатами міжнародних досліджень, рейтинги України за окремими індексами, що стосуються впровадження інформаційних технологій на 2012 рік склали [5]: - глобальний індекс конкурентоспроможності 2011-2012 pp. (WEF Global Competitiveness Index) - 82 місце (89 - у 2011 р.) із 142 країн; індекс технологічної готовності 2011-2012 pp. (WEF Technological Readiness Index) - 82 місце із 142 країн; індекс мережевої готовності 2011-2012 pp. (WEF Networked Readiness Index $)-75$ місце $(90$ - у 2011 р.) iз 142 країн; Е-готовність уряду (Government readiness) 122 місце із 138 країн; використання урядом IКТ (Government usage) - 75 місце iз 138 країн; рейтинг за електронною готовністю 2010 (EIU eReadiness Ranking) 64 місце із 70 країн; індекс електронного уряду ООН 2012 (UN e-Government Index) - 68 місце (54 - у 2011 p.) із 193 країн. Якщо порівняти рівень проникнення IT в Україні з рівнем проникнення у таких країнах, як Росія та США, то наочно можна побачити, що хоча за кількістю користувачів Україна значно відстає, але за темпами розвитку значно випереджає (табл. 1,2$)$ [6].

Таблиця 1

Відсоток осіб, які мають доступ до мережі «Інтернет»

\begin{tabular}{|c|c|c|c|c|c|}
\hline Країна & $\mathbf{2 0 0 8} \mathbf{p .}$ & $\mathbf{2 0 0 9} \mathbf{p .}$ & $\mathbf{2 0 1 0} \mathbf{p .}$ & $\mathbf{2 0 1 1} \mathbf{p .}$ & $\mathbf{2 0 1 2} \mathbf{p .}$ \\
\hline Україна & $11,00 \%$ & $17,90 \%$ & $23,30 \%$ & $30,60 \%$ & $41,4 \%$ \\
\hline Росія & $26,83 \%$ & $29,00 \%$ & $43,00 \%$ & $49,00 \%$ & $56,5 \%$ \\
\hline США & $74,00 \%$ & $71,00 \%$ & $74,00 \%$ & $77,86 \%$ & $81,1 \%$ \\
\hline
\end{tabular}

За період 2008-2013 рр. кількість абонентів зв’язку в України зросла на 11,25 \%, з них кількість абонентів кабельного телебачення на 1,83 \%, а користувачів мережі «Інтернет» на 165,78 \%.

Таблиця 2

Динаміка проникнення IКТ у період 2008-2012 pp.

\begin{tabular}{|c|c|c|c|c|c|}
\hline Країна & $\mathbf{2 0 0 9 / 2 0 0 8}$ & $\mathbf{2 0 1 0 / 2 0 0 9}$ & $\mathbf{2 0 1 1 / 2 0 1 0}$ & $\mathbf{2 0 1 2 / 2 0 1 1}$ & $\mathbf{2 0 1 1 / 2 0 0 8}$ \\
\hline Україна & $62,73 \%$ & $30,17 \%$ & $31,33 \%$ & $35,29 \%$ & $178,18 \%$ \\
\hline Росія & $8,09 \%$ & $48,28 \%$ & $13,95 \%$ & $15,31 \%$ & $82,63 \%$ \\
\hline США & $-4,05 \%$ & $4,23 \%$ & $5,22 \%$ & $4,16 \%$ & $5,22 \%$ \\
\hline
\end{tabular}

Основними сегментами на ринку телекомунікаційних послуг залишаються мобільний, фіксований та широкосмуговий (комп'ютерний) зв'язок, спільна частка яких у загальних доходах від надання телекомунікаційних послуг у I кварталі 2013 року склала 94,2 \%. Слід зазначити, що Донецька, Одеська, Львівська області характеризуються найбільшим рівнем проникнення IKT, порівняно 3 іншими областями України, найнижчим рівнем проникнення характеризуються Кіровоградська, Житомирська, Івано-Франківська області [7]. За даними Держкомстату, за показником проникнення доступу в Інтернет серед підприємств лідирує Київ, де його мають біля 95 \% підприємств. У промислових регіонах цей показник становить вище 85-87 \%, серед аутсайдерів Чернівецька та Хмельницька області, де лише 72-75 \% мають доступ в Інтернет. 
Google $є$ лідером серед пошукових систем в Україні: $60 \%$ переходів на інші сайти відбуваються саме 3 нього. На другому місці - Yandex (30 \%), далі йде mail.ru (7 \%) та ін. За оцінками компанії Gemius-Україна, ТОП5 сайтів мають дещо іншу картину: Google.com, Mail. ru, Vk.com, Yandex.ua, Youtube.com. Соціальна мережа Odnoklassniki.uа в червні 2013 р. піднялася на 6 позицію, Wikipedia.org - опустилася на 7, Facebook.com піднялася на 8 позицію рейтингу з охопленням [8]. За даними iKS-Consulting очікується зниження темпів зростання кількості користувачів широкосмугового доступу до Інтернет, які у 2015 р. знизяться до $10 \%$. Вочевидь це пов'язане з поступовим насиченням ринку. Ця ж компанія визначає найбільшими провайдерами широкосмугового Інтернет «Укртелеком», «Київстар», «Воля», які охоплюють більше половини цього ринку.

Трендом 2013 року стали бізнеси-інкубатори. В 2012 р. сума інвестицій в стартапи, що ініційовані українськими компаніями, склала \$30-50 млн. Зараз у світі існує дефіцит гарних проектів і тому інвестиційні фонди західних країн і Росії починають вкладати гроші в українські IT-проекти. У 2013 р. створений перший в Україні грантовий фонд в галузі інформаційних технологій - Global Technology Foundation (GTF), що планує підтримувати - IT-проекти в сфері державних послуг, зв'язку, медіа, освіти, охорони здоров'я, хмарових обчислень. Стандартний розмір фінансової підтримки - 240 тис. грн. Міжнародний ринок послуг 3 програмування активно освоюють нові гравці - країни Азії та Південної Америки. За даними дослідження впливової аналітичної агенції Gartner за 2013 рік з Україною співпрацювали $3,1 \%$ опитаних компаній, а з такими країнами, як Марокко, Маврикій, ПАР - 12,2 \%, 7,9 \% та 12 \% відповідно.

В Україні для підтримки IT-галузі були прийняті закони «Про державну підтримку розвитку індустрії програмної продукції» та були внесені зміни в Податковий кодекс України, що встановлюють особливий порядок оподатковування для IT-сфери. Незважаючи на це, діючі в
Україні умови для розвитку IT-бізнесу за обсягом стимулів для розвитку відповідної галузі значно поступаються тим, що створені у традиційних аутсорсингових локаціях, зокрема в Індії, Росії, Білорусі. Окрім того, практичне застосування відповідних норм Податкового кодексу не відпрацьовано на рівні деталізації, що забезпечувало б безперешкодне використання зазначених пільг. Як наслідок, протягом року після прийняття відповідного законодавства, спеціальним режимом оподаткування для IT компаній скористалися близько 200 IT компаній з більше ніж 2000, що свідчить про невідповідність наданих стимулів потребам бізнесу.

Висновки та перспективи подальших досліджень. Ступінь розбудови інформаційного суспільства в Україні стримується такими перешкодами: недосконала загальнодержавна політика, політична та економічна нестабільність; недосконалість законодавства; низька інвестиційна активність; відсутність єдності державної технічної та інвестиційної політики; впровадження електронного урядування уповільнено та недостатньо координовано; відсутність мотивації та координації дій операторів телекомунікацій; наявність значного «цифрового розриву» у використанні IКТ; загострення проблем та ризиків, пов'язаних з інформаційною безпекою. На думку авторів, в умовах, що склалися на українському інформаційному та телекомунікаційному ринку, доцільним $\epsilon$ висунення таких пропозицій: підвищення технологічного рівня галузі; створення сприятливого інвестиційного клімату для залучення інвестицій; створення програми координації дій та підтримки державою вітчизняних операторів телекомунікаційної сфери; створення належного законодавчого підгрунтя функціонування галузі; надання певних пільг для розвитку виробництва та впровадження телекомунікаційного устаткування на території країни; активне співробітництво суб'єктів підприємництва між собою та 3 науково-дослідними інститутами, що дозволить залучити наукові кадри та уникнути дублювання мереж різних операторів.

\section{Література}

1. Булах І. В. Оцінка конкурентоспроможності підприємства електрозв'язку : автореф. дис. канд. екон. наук: 08.00 .04 / OHA3. - O., 2008. - $20 \mathrm{c}$.

2. Кораблінова I. А. Управління конкурентоспроможністю операторів телекомунікацій у сучасних умовах : автореф. дис. на здоб. наук. ступеня канд. екон. наук: спец. 08.00.04 - економіка та управління підприємствами (за видами економічної діяльності) / І. А. Кораблінова. - Одеса, 2011. - 22 с.

3. Закон України «Про національну інформатизацію». [Електронний ресурс]. - Режим доступу: http://zakonl.rada.gov.ua/laws/ show/1280-15

4. E. Bornman. The Mobile Phone in Africa: Has It Become a Highway to the Information Society or Not? - Contemporary Educational technology, 2012, 3(4), 278-292. - www.cedtech.net/articles/34/343.pdf

4. Державний комітет статистики України. - Офіц. веб-сайт. [Електрон. pecypc]. - Режим доступу: http://www.ukrstat.gov.ua.

5. Проект стратегії розвитку інформаційного суспільства в Україні. [Електронний ресурс]. - Режим доступу: nc.gov.ua/news/ strategists31_07_2012.doc

6. Статистична служба ООН Undata - Офіц. веб-сайт. - Режим доступу: http://data.un.org/. 
7. Офіц. веб-сайт Національної Комісії, що здійснює державне регулювання у сфері зв’язку та інформатизації. - Режим доступу: http://www.nkrz.gov.ua

8. http://itc.ua/articles/sostoyanie-i-perspektivyi-onlayn-torgovli-v-ukraine-po-materialam-konferentsii-owox-2012.

9. Наукові записки Українського наук.-дослід. інст. зв'язку. - 2012. - № 3 (11). - С. 93-101.

10. Стрельчук Є. М. Стратегія розвитку оператора зв'язку : монографія / Стрельчук С. М., Петрашевська А. Д. - О. : Фенікс, 2007. $-111 \mathrm{c}$

Стаття надійшла 15.10.2014

Рецензент: Савенко I.I., доктор економічних наук, завідувач кафедри менеджменту і логістики Одеської національної академії харчових технологій

Седикова И.А.

кандидат экономических наук, доцент

кафедра менеджмента и логистики

E-mail: irina-sedikova@rambler.ru

Одесская национальная академия пищевых технологий

ул. Канатная, 112, г. Одесса, Украина, 65039

Седиков Д.В.

студент 3-го курса

факультет системы технической защиты информации

E-mail: sedikov94@mail.ru

Одесская национальная академия связи им. А.С. Попова

ул. Кузнечная, 1, г. Одесса, Украина, 65029

\title{
СОВРЕМЕННОЕ СОСТОЯНИЕ ТЕЛЕКОММУНИКАЦИОННОГО ПРОСТРАНСТВА УКРАИНЫ
}

Проведено исследование состояния развития информационного и телекоммуникационного рынка Украины. Установлено, что тенденции развития отрасли характеризуются ростом доходов от всех форм деятельности. Доказано, что ускоренным темпом развиваются услуги кабельного телевидения, а также доступа к сети «Интернет». Определено, что основными сегментами на рынке телекоммуникационных услуг остаются мобильная, фиксированная и компьютерная связь, проведен анализ рейтинга поисковых систем.

Ключевые слова: информация, телекомуникации, информационное пространство, информатизация, информационные технологии.

\author{
Sedikova I.A. \\ PhD, Associate Professor \\ Department of Management and Logistics \\ E-mail: irina-sedikova@rambler.ru \\ Odessa National Academy of Food Technologies \\ Kanatnaya Street, 112, Odessa, Ukraine, 65039 \\ Sedikov D.V. \\ student of 3rd year \\ Faculty The System of Technical Protection of Information \\ E-mail: sedikov94@mail.ru \\ Odessa National Academy of Telecommunications named A.S. Popov \\ Kowalska Street, 1, Odessa, Ukraine, 65029
}

\section{THE CURRENT STATE OF THE TELECOMMUNICATIONS SPACE OF UKRAINE}

Abstract. Relevance of the study of the topic is determined by the fact that one of the global trends is the development of the information society. Virtually all experts, economists, politicians realized that the development of IT creates foundations of modern economics and human welfare. The study is based on scientific papers studied by many scientists available modern information technologies, their use and impact on development.

The article is a study of the development of information and telecommunication market of Ukraine.

Determined that Ukraine is moving in the development of information society slowly. As noted in the "Annual Report on the state of information and the development of information society in Ukraine for 2013", the country at the current pace of IT development is lagging behind other countries, as observed today. Established that trends in 
the industry are characterized by increased revenue from all forms of activity. It is proved that the accelerated pace of development services use to provide cable TV and access to the «Internet». Proved major segments in the market of telecommunications services are mobile, fixed and broadband (computer) connection. The analysis made it possible to conclude that Donetsk, Odessa, Lviv region is characterized by the highest levels of ICT penetration in comparison with other regions of Ukraine. This study analyzes search engine ranking and determined their rating. The conclusions on the feasibility of such proposals: raising the technological level of industry; creating a favourable investment climate; creation program coordination and support of the local telecom operators sector; creating appropriate legislative framework for the industry.

Keywords: information, telecommunications, information space, information technology.

\section{References}

1. Bulakh I. V. (2008). Otsinka konkurentospromozhnosti pidpryiemstva elektrozviazku : avtoref. dys. kand. ekon. nauk: 08.00 .04 . ONAZ, O., 20.

2. Korablinova I. A. (2011). Upravlinnia konkurentospromozhnistiu operatoriv telekomunikatsii u suchasnykh umovakh : avtoref. dys. na zdob. nauk. stupenia kand. ekon. nauk: spets. 08.00.04 - ekonomika ta upravlinnia pidpryiemstvamy (za vydamy ekonomichnoi diialnosti). Odesa, 22.

3. Zakon Ukrainy «Pro natsionalnu informatyzatsiiu». [Elektron. resurs]. Rezhym dostupu: http://zakonl.rada.gov.ua/laws/ show/1280-15.

4. E. Bornman. (2012). The Mobile Phone in Africa: Has It Become a Highway to the Information Society or Not? - Contemporary Educational technology, 3(4), 278-292, www.cedtech.net/articles/34/343.pdff.

4. Derzhavnyi komitet statystyky Ukrainy. Ofits. veb-sait. [Elektronnyi resurs]. Rezhym dostupu: http://www.ukrstat.gov.ua.

5. Proekt stratehii rozvytku informatsiinoho suspilstva v Ukraini. [Elektronnyi resurs]. Rezhym dostupu: nc.gov.ua/news/ strategists31_07 2012.doc.

6. Statystychna sluzhba OON Undata. Ofits. veb-sait. Rezhym dostupu: http://data.un.org.

7. Ofits. veb-sait Natsionalnoi Komisii, shcho zdiisniuie derzhavne rehuliuvannia u sferi zviazku ta informatyzatsii. Rezhym dostupu: http://www.nkrz.gov.ua.

8. http://itc.ua/articles/sostoyanie-i-perspektivyi-onlayn-torgovli-v-ukraine-po-materialam-konferentsii-owox-2012.

9. Naukovi zapysky Ukrainskoho nauk.-doslid. inst. zviazku. 2012, 3 (11), 93- 101.

10. Strelchuk Ye. M., Strelchuk S. M., Petrashevska A. D. (2007). Stratehiia rozvytku operatora zviazku: monohrafiia. O.: Feniks, 111. 